\title{
En æstetisk filosofi om sanseoverskridende erfaringer
}

\author{
Lektor dr. theol. \\ Lars Albinus
}

Dorte Jørgensen, Den skønne tonkning. Veje til erfaringsmetafysik Religionsfilosofisk udmøntet, Dorthe Jørgensen. Aarhus: Aarhus Universitetsforlag 2014. 965 s. Kr. 499,95.

\begin{abstract}
The full doctoral thesis, The Beautiful Thinking, by the Danish Historian of Ideas Dorthe Jørgensen, is an impressive and erudite work that challenges modern theology to learn from philosophical aesthetics or, more specifically, a 'metaphysics of experience'. Taking her point of departure in Baumgarten's concept of sensitive cognition, she sets out to develop a philosophy which, contrary to the erratic strictures of empirical science, on the one hand, and superficial tendencies of the modern entertainment culture, on the other, is able to grasp experiences of ' $\mathrm{im}$ manent transcendence' or 'a surplus of meaning'. In this review article, however, I warn against the romanticizing implications of this endeavor inasmuch as the subject matter of theology is a confessional tradition rather than some form of experiential sensitivity.
\end{abstract}

Keywords: Sensitivity, immanent transcendence, surplus of meaning, aesthetics, religious experience.

\section{Disputatsen}

Der er meget på spil i Dorthe Jørgensens omfattende afhandling, der efter offentligt forsvar d. 21 marts 2014 blev tildelt den teologiske doktorgrad ved Aarhus Universitet. Uden at yde dens emnemæssige spændvidde retfærdighed, vil jeg først og fremmest forholde mig til den som et filosofisk udspil ind i en teologisk kontekst. Afhandlingen tager sit afsæt i det emneområde, som forfatteren gennem mange år har gjort til sit særlige fagområde, nemlig filosofisk æstetik. I den forbindelse er det en mærkesag for hende på den ene side at lægge afstand til en udbredt forståelse af filosofisk æstetik som kunstfilosofi og på den anden side at holde sig fri af den i hendes øjne fordummende 'oplevelsesøkonomi', der er oppe i tiden. De to klippeskær, forfatteren grundlæggende vil styre sit filosofiske flagskib imellem, 
er til den ene side et snævert empirisk funderet erfaringsbegreb og til den anden den pirrende sanseoplevelses lige så endimensionale niveau. Sit idéhistoriske udgangspunkt tager hun i Alexander Gottlieb Baumgartens distinktion mellem en logisk og en æstetisk erkendelse, hvilket idéhistorisk grundlægger æstetikken som en selvstændig filosofisk disciplin. Dermed banes vejen samtidig for en ny måde at tænke metafysik på, selvom dette først lader sig realisere ad omveje, som ikke mindst inkluderer Immanuel Kants, Walter Benjamins og Martin Heideggers kritik af den traditionelle, fornuftsbaserede metafysik. Jørgensen vil med stort indblik i Baumgartens forfatterskab læse det fri af tidligere udlægningers manglende sans for den æstetiske tænknings potentiale. Til trods for den rationalistiske "spændetrøje", som hun indrømmer, at hans tænkning udfolder sig inden for, fremlæser hun ikke desto mindre på overbevisende måde af hans Aesthetica en foregribelse af det romantiske begreb om følelsen som en form for erkendelse, der ikke kan underlægges den deduktive fornuftsdom. Om Baumgartens brug af adjektivet sensitivus fastslår hun, at det "nærmere bestemt (betegner) noget, der ikke kun er sanseligt, men også følelsesmæssigt, dvs. udsprunget af et konglomerat af folelse, fornemmelse og anelse" (108). Denne begrebstreenighed, som forbliver et gennemgående tema $\mathrm{i}$ afhandlingen, betegner på den ene side det afsæt, forfatteren således tager i Baumgartens tænkning, men angiver på den anden side også det metodiske grundlag for hendes eget erfaringsmetafysiske udspil. Det er denne erfaringsmetafysik, som det er afhandlingens hovedformål at udfolde religionsfilosofisk, hvilket også fremgår af, at Jørgensen har valgt at indlevere sin afhandling til forsvar for den teologiske doktorgrad.

Forholdet mellem teologi og erfaringsmetafysik.

I et opgør med den filosofiforskrækkelse, der ifølge Jørgensen præger dagens akademiske verden, spiller hun ud med en erfaringsmetafysik forstået som en "filosofi, der under sin udforskning af de erfaringer, der er dens genstand, forsøger at lægge bevidsthedsfilosofiens subjekt/ objekt-strukturerede tankegang bag sig for således at komme tættere på og få bedre indsigt i den mellemverden, som de pågældende erfaringer udgør" (ibid.). Denne mellemverden refererer altså hverken til en suveræn subjektivitet eller en selvberoende objektivitet, men derimod til erfaringsfeltet for en "modtagende skaben" (333), der med tilskud af Heideggers begreber om den menneskelige tilstedeværens stemthed og befindlighed iscenesætter det, Jørgensen med reference 
til sig selv (42, n. 45) og Mark C. Taylor (736), betegner som "immanent transcendens". Den hævdede mulighed for at erfare - og filosofisk koncipere - immanent transcendens eller "merbetydning", som hun også kalder det, er således det, der bringer erfaringsmetafysikken i dialog med teologien. Ifølge Jørgensen deler teologien nemlig genstandsfelt med æstetikken i kraft af "et 'noget', som henholdsvis skønhedserfaringen og den religiøse erfaring er rettet mod" (564f). Måske er det for meget sagt, at Dorthe Jørgensen inviterer til en dialog med teologien, for det fremgår klart, at det snarere er teologien, der har noget at lære af erfaringsmetafysikken end omvendt, hvis teologien ellers er indstillet på at tage den almindelige menneskelige erfaringshorisont alvorligt (43f; 557; 568; 576-8; 617f; 757). ${ }^{1}$ Den risiko, Jørgensen først og fremmest advarer imod, er, at teologien påvirkes så meget af en poststrukturalistisk og videnskabsforgudende "transcendensforskrækkelse" (542; 546), at den glemmer sit egentlige genstandsområde, nemlig Gud og Gudserfaringens mulighed, og i stedet forskriver sig til religionsvidenskabelige studier af traditionen. Når den filosofiske æstetiks erfaringsmetafysik ikke desto mindre adskiller sig fra teologien, skyldes det, at den ikke bare er en lære (logos) om Gud (theos), men en langt mere inkluderende tænkning om det, der principielt overskrider den empiriske erkendelsesdoms prædikative logik. Af samme grund efterlyser Jørgensen en skelnen mellem 'det transcendente', som udgør religionens genstandsfelt, og 'transcendens' i ubestemt form, som erfaringsmetafysikken netop retter sit blik imod. "Man kan forestille sig en sådan genstandsløs erfaring af immanent transcendens", skriver hun, "i hvilken transcendensen ikke er substantiveret til noget transcendent, men derimod er ren bevægelse og nærmere bestemt en bevægelse på stedet, eftersom den ikke fører tanken over i noget andet end det immanente, da erfaringen som sagt er genstandsløs” (544). Nu vover Jørgensen imidlertid også at tale om "transcendenserfaringer" i positiv forstand ud fra en kritik af det, hun betragter som en dogmatisk og transcendensforskrækket fastholdelse af immanensen som udsigelsesramme. ${ }^{2}$ Forskellen er altså, at hun betragter det immanente, forstået som den verden der umiddelbart omgiver os, som det sansebetingede grundlag for sensitive erfaringer af noget 'mere'. Det er den religionsfilosofiske udmøntning heraf, som hun anbefaler teologien at tage ad notam (718).

1. Der levnes dog også plads til "noget i æstetikken, hvorom teologien er bedre orienteret", nemlig den del, der har "affinitet til det religiøse" (603).

2. I den forbindelse retter hun en ikke helt rimelig kritik imod det, hun betragter som "Deleuzes forkærlighed for empirisme" (542f). Den måde, hvorpå det immanente hos Deleuze folder sig ind over sig selv i begrebet, er udtryk for en selvoverskridende bevægelse, som Jørgensen ikke tilstrækkeligt giver ham kredit for. 
Erfaringsmetafyikkens filosofiske afsæt.

Når hun i den ovenfor beskrevne bestemmelse af erfaringsmetafysikken hævder at ville lægge afstand til bevidsthedsfilosofien (13; 81; 570), spørger man sig selv om, i hvilken forstand hun da kan forstå sin nye filosofi som en udforskning af erfaringer? Ganske vist udvinder hun med stor kyndighed Kants begreb om det almene ved smagsdommen i en gentænkning af Baumgartens begreb om æstetisk erkendelse og vil samtidig gøre sig fri af den tingsliggørende subjektobjekt-dualisme, som definerede rammerne om Kants erkendelsesbegreb, men det er bestemt ikke ensbetydende med at bevæge sig ud over bevidsthedsfilosofien i bred forstand! Jørgensen betjener sig af formuleringer, der lader formode, at hun ligestiller bevidsthedsfilosofi med den refleksive forankring i et aktivt erkendende subjekt (se fx 639), men spørgsmålet er, om det receptivt skabende subjekt, hun stiller op som et alternativ, ikke er forankret i en meget beslægtet form for subjekt-orienteret tænkning. Det, Jørgensen først og fremmest bevæger sig væk fra i forhold til det, hun forstår ved subjektfilosofi, er, så vidt jeg kan se, udartninger i form af empirisk objektivisme (jf. hendes videnskabskritik) på den ene side og en oplevelsesbaseret subjektivisme (jf. hendes kritik af oplevelsesøkonomien) på den anden. Når hun som modvægt hertil henviser til en erfaring af 'noget' (dvs. merbetydning eller immanent transcendens), der vederfares et agtpågivende og fantasifuldt subjekt, ser hun ser sig selv i forlængelse af de forsøg på at knytte erfaring, sandhed, væren og sprog sammen, som på forskellig måde kommer til udfoldelse hos Benjamin og Heidegger. Men hvor vægten netop ligger i sproget som det, der hos Benjamin rummer muligheden for en 'højere erfaring' end den med prædikatslogikken forbundne erkendelse af verden, og hvor Heidegger i alt væsentligt knytter væren og sprog sammen (uanset hvorvidt det sene begreb om 'gelassenhed' peger i en ny retning eller ej, (141)), hæfter Jørgensen sig primært ved selve erfaringsaspektet og falder dermed i alt væsentligt bagom den sproglige vending, ${ }^{3}$ der normalt betragtes som en af hovedvejene ud af bevidsthedsfilosofien.

Det, der præger den udbredte opfattelse af en sproglig vending i det 20. århundredes filosofi, er i langt højere grad en diagnosticering af erfaringens sproglige og kommunikative forudsætninger end behovet for en 'højere form for erkendelse'. Dette gælder endog Benjamin, selvom han ganske rigtigt i sine yngre dage med inspiration fra Kabbala-mystikken og den tidlige tyske romantik også havde et

3. Dette bekræftes endvidere af Jørgensens egen tilslutning til Susanne Langers opfattelse af, at sprogets grænser ikke er "erfaringens yderste grænser, og ting, der er utilgængelige for sproget, kan måske have deres egne forestillingsformer” (513). 
‘højere erfaringsbegreb’ for øje. Dog var det ikke knyttet til en tidløs, æstetisk følsomhed, men til en forfaldshistorie og en hermed forbundet forløsningstanke. Det var denne historiske dybdedimension, Benjamin savnede hos Heidegger, som endnu i Varen og Tid nøjedes med at tale om historicitet i fænomenologisk forstand. Når Jørgensen derfor, til trods for hendes blik for denne forskel, lader begge positioner bidrage til udviklingen af en erfaringsmetafysik, risikerer hun at efterlade et trivialiserende blik på deres tænkning uanset den plads og grundighed, hun vier de æstetisk-filosofisk relevante dele af deres forfatterskaber.

Det problem, jeg først og fremmest har med dette ambitiøse projekt, er den enstrengede polarisering, der til trods for afhandlingens rigt facetterede diskussioner, præger hendes videnskabskritiske positionering, og som i sidste ende sår tvivl om det berigende i alternativet. For det første er det ligeså forenklende at tale om filosofiforskrækkelse i almindelighed, som det er at skære al videnskabelig erkendelse over en kam. For det andet er den modstilling mellem sansning og ånd, som Jørgensen (utilsigtet eller ej) forskriver sig til, udtryk for en dualisme, som ikke styrker hendes forsøg på at tænke 'en mellemverden'. I modsætning til Løgstrup, for hvem sansning og forståelse hænger uadskilleligt sammen (628), tyer hun til en særlig form for subjekt- og objekttranscenderende sensitivitet, der lægger afstand til den blotte sansning. Med denne reduktion af sanseerfaring til ren og skær impuls for en åndelig erkendelse abonnerer hun imidlertid på en begrebslig polarisering, som ikke overvindes af selve postulatet om 'sensitivitet'.

Når Jørgensen derfor med en sanseoverskridende sensitivitet i ryggen adopterer begrebet immanent transcendens, har hun angiveligt en erfaringsform i tankerne, som viderefører dualismen mellem sansning og ånd i en tilsvarende kløft mellem immanens og transcendens. Da hun imidlertid hverken kan eller vil bruge erfaringsmetafysikken til at indhente "en Hinterwelt af absolutte referenter" (543), hvilket fortsat er forbeholdt religionen, stiller hun i stedet for skarpt på den følsomme erfarings selvoverskridende karakter. Spørgsmålet er imidlertid, hvad der ligger i denne selvoverskridelse? Jørgensen gør det klart, at erfaringsmetafysikken orienterer sig langt bredere en kunstfilosofien. Den er i virkeligheden en form for fænomenologi, der med bl.a. Heidegger (uden at han selv indså det) har realiseret den æstetiske filosofis erfaringssensitive potentiale. Hvis man imidlertid kigger efter de sparsomme eksempler, hun giver på transcendenserfaringer, finder man enten eksempler fra kunstens verden (fx 300f; 721) eller, undskyld mig, lidet sigende, 'verdenspoetiske' henvisninger til lyset, 
der bryder gennem skydækket, og en dør, der går på klem (567). ${ }^{4}$ Dog vies bønnen - og ikke mindst det, hun med Christoph Klein (763) kalder for en 'grænseoverskridende bøn' - en afgørende opmærksomhed som "rum for den æstetiske tænkning" (773), idet den som religiøst fænomen tænkes sammen med den filosofiske tankes tak til verden, som hun bl.a. kan tage Dieter Henrich og Heidegger til indtægt for (788). Dog ligger det vel lige for, at bønnen ikke udgør erfaringsmetafysikkens genstand men dens middel. Som læser efterlades man derfor lidt i vildrede om, hvad det egentlig er erfaringsmetafysikken åbner op for.

\section{Hvad kan teologien lære af erfaringsmetafysikken?}

Spørgsmålet er endelig, hvad teologien kan lære af erfaringsmetafysikken, som Jørgensen forestiller sig den. Selvom hun betragter den religiøse erfaringsmulighed som teologiens genstandsområde og bogstavtro forstår teologi som læren om Gud $(576 ; 600)$, går hun den nødvendige omvej omkring de former for teologi, som på forskellig måde har forholdt sig reflekteret til tanken om Guds død. I Jørgensens optik betyder denne modernitetserfaring imidlertid ikke, at teologien har råd til at lade hånt om den alment menneskelige sensitivitet og dermed afskære sig fra muligheden for at relatere transcendenserfaringer til dens eget dogmatiske vokabular. Hun hævder, at "den protestantiske teologi" (herunder Eberhard Jüngel og K.E. Løgstrup) "har brug for at revidere sin opfattelse af centrale æstetikteoretiske begreber" og henviser bl.a. til den teologiske æstetik hos David Bentley Hart og Hans Urs von Balthasar. For Balthasar må teologien således, som hun formulerer det, "reflektere over erfaringen af Guds herlighed, der er den kristne tros genstand", hvis den ikke skal ende i "eksakt videnskab" (594). Det er selvfølgelig vand på Jørgensens egen mølle, for dermed må et empirisk vidensbegreb vige pladsen for skønhedsmetafysiske betragtninger over Guds væsen. Jeg spørger imidlertid mig selv, om det primært er teologiens rolle at forholde sig til spørgsmål om "en objektiv herlighed subjektivt opfattet af troen" (595)? Ét er, at en sådan spørgehorisont snarere befinder sig inden for den subjekt-objekt dualisme, som Jørgensen eksplicit vil erstatte med en 'mellemverden', noget andet er, at det i det mindste er omstridt, hvorvidt en moderne teologi kan eller bør se sig selv som en

4. Jørgensen citerer hermed sit eget forord til Verdenspoesi: Malerier og tankebilleder af filosof Dorthe Jørgensen og billedkunstner Bettina Winkelmann (Aarhus: Kvindemuseets Forlag 2011). 
lære om Gud, endsige har religiøse erfaringer som genstand. For mig at se har teologien først og fremmest en forkyndelsestradition som objekt. Selvfølgelig kan troens institutionelle, historiske og eksistentielle udtryksformer ikke anskues isoleret fra det udsagte trosindhold, men ved at flytte dette over i en generaliserende erfaringsmetafysik, der som i romantikken har den endelighedsoverskridende følsomhed som afsæt og inderste begrundelse, risikerer man at banalisere teologien. Som jeg ser det, har den nemlig ikke mere eller mindre vidtløftige troserfaringer, men derimod trosbekendelsen, som sit udgangspunkt. Det ofte tematiserede krav til den kristne gudstjeneste (og dermed også indirekte til teologien) om, at den skal komme moderne menneskers forståelseshorisont i møde, er til dels et krav, der er betinget af folkekirkens institutionelle rolle i det danske samfund. Men dette må ikke forveksles med et krav til selve forkyndelsen endsige til teologiens genstandsfelt. Ingen af delene er nemlig bestemt gennem en "subjektivt opfattet tro", men af et budskabs overlevering. Den akademiske teologis primære anliggende er i mine øjne at forholde sig refleksivt, dvs. såvel empirisk videnskabeligt som 'systematisk' spørgende, til et institutionaliseret kompleks af lære og praksis, der generation på generation har udfoldet sig omkring dette budskab. Selvfølgelig har teologien en aktualiserende forpligtelse, men det er en forpligtelse, der må ses i forhold til en historisk horisont, hvor fortid og nutid gensidigt betinger hinanden. Godt nok kan teologien på Augustins tid siges at være læren om Gud, men allerede hos Luther trådte Guds uransagelighed i baggrunden for det ord, der stedfortrædende er overleveret os. For en teologi, der vil tage den sproglige vending alvorligt (hvilket selvfølgelig ikke er givet) vejer løftet og bekendelsen tungere end oplevelsen - eller den hævdede erfaring - af 'noget mere'. Dermed ikke sagt, at den filosofiske æstetik eller fænomenologi ikke kan sige noget om denne 'erfarings' mulighedsbetingelser, men det er nu engang ikke disse betingelser, der gør teologi til teologi.

Jørgensen synes at tænke anderledes. Med udgangspunkt i bl.a. Løgstrups Heidegger-inspirerede tanker om stemthed, forsøger hun at revitalisere en teologisk-æstetisk spørgehorisont, der ikke som hos Løgstrup selv 'nøjes' med at være kunstfilosofisk orienteret. Efter hendes mening blokerer en sådan restriktion nemlig i sidste ende for en tilstrækkeligt vidtgående teologisk konception af almene æstetiske erfaringer. "Det fører ingen vegne", skriver hun, "at pansre sig doktrinært i sin tilgang til erfaringerne og stille krav om, at de umiddelbart giver indtryk af tro - med alt, hvad det i nyere tid har medført af mistro til aisthesis og uvilje mod skønhed. Teologien må i stedet nærme sig erfaringerne i forventning om, at de faktisk rummer noget, der er værd at udlægge teologisk" (617). Hvis jeg forstår hende ret, 
finder hun det altså problematisk, at teologien med sine trosdoktriner i ryggen vender det døve øre til "vore egne erfaringer" (ibid.). Men om en given prædiken ved søndagsgudstjenesten vinder ved at inddrage erfaringer, alle kender til, betyder vel ikke, at teologien som sådan handler om, hvilke erfaringer vi hver især gør os. At allehånde oplevelser, forestillinger og erfaringer kan udlægges teologisk, kan jeg ikke være uenig med Jørgensen i, men det er bestemt ikke det samme som at teologien skulle have et særligt forhold til, endsige være forpligtet på, et specifikt erfaringsmetafysisk genstandsfelt. De helt almindelige dagligdags erfaringer af brød på bordet er for den sags skyld fuldt ud lige så teologisk relevante som anelser 'af noget mere'.

\section{Afrunding (fra fornemmelse til forkyndelse)}

Jeg deler ikke Jørgensens udifferentierede videnskabs- og empiriforskrækkelse og betragter da slet ikke dette erkendelsesgrundlag som et problem for teologien. Tværtimod har den kritisk-videnskabelige undersøgelse af traditionen specielt $\mathrm{i}$ en kontinental kontekst frisat teologiens forhold til trosspørgsmålet, så det ikke længere drejer sig om at sikre en eller anden form for Gudserkendelse (der fortsat spøger i megen af den angelsaksiske religionsfilosofi, som også optager Jørgensen), men derimod om et eksistentielt anliggende i forhold til forkyndelsen. Dermed ikke sagt at teologien skal forkynde. Men forkyndelsestraditionen er og bliver dens primære genstand, som jeg ser det.

Selvom jeg har lidt svært ved at få hold på, hvad Jørgensens filosofisk-æstetiske begreb om erfaring egentlig dækker over, er skønheden fremhævet som det helt centrale karakteristikum, og skønheden er vel at mærke ikke alene genstand for den 'sensitive erfaring', men også det prædikat, der udmærker den som tænkning. Selvom det 'at tænke skønt' er hentet fra Baumgarten, er der ingen tvivl om, at Jørgensen i sin egen konception af en æstetisk tænkning tillægger det nogle langt videre konnotationer. Men hvorfor i det hele taget tænke skønt? Er en tanke, der ikke viger tilbage for at tænke det grimme eller ubehagelige, mindre filosofisk, fornemmende, følende eller anende? Er verdens grusomhed og endelighedens ubønhørlighed (og her tænker jeg ikke blot på "en brudt skønhed i det uperfekte" (713)) mindre central for teologien, når det nu engang drejer sig om den menneskelige erfaringsverden, end forestillingen om Guds herlighed? Kan det håb, som har sin grund i et overleveret løfte, reduceres til, endsige sidestilles med, en skønhedserfaring? Skal teologien hente sit lys fra sprækken 
i skydækket eller i ordet, der også lyder til den, for hvem den totale erfaringshorisont er tømt i håbløshed?

Hvis ikke teologien talte et radikalt andet sprog end erfaringsmetafysikken, kunne den i princippet erstattes af kunsten eller tilvejebringelsen af ekstatiske sindstilstande, men som teologi er den allerede, hvad den er, dvs. bundet til en tradition af og som fortsat selvtilegnelse, uanset hvilke behov den måtte tjene til at tilfredsstille, eller hvilke ydre krav omverdenen måtte stille til den.

For mig at se indlægger Dorthe Jørgensens afhandling sig størst fortjeneste ved sin imponerende, idehistoriske fremstillingskraft. Her er der meget, teologien kan lade sig inspirere af. Når det specifikt drejer sig om de anslåede veje til en erfaringsmetafysik, må jeg imidlertid advare den teologiske selvrefleksion om at støtte sig til en generaliserende indfaldsvinkel, der flytter fokus fra forkyndelse til følelse og fornemmelse. 